\title{
喿Iresalce \\ A experiência da realidade virtual com crianças em procedimentos dolorosos
}

\author{
The experience of virtual reality with children in painful procedures
}

\section{Marcela Barbosa de Farias ${ }^{1}$, Ingrid Martins Leite Lúcio² ${ }^{2}$, Ana Carolina Santana Vieira $^{3}$, Maria Cícera dos Santos de Albuquerque ${ }^{4}$}

\section{Resumo}

Introdução: Durante a hospitalização infantil, a realização de procedimentos dolorosos reflete no bem-estar, comunicação e continuidade da assistência à saúde ${ }^{1}$. Uma das preocupações da equipe de enfermagem trata-se do alívio da dor e conforto da criança, especialmente em procedimentos invasivos ${ }^{2}$. Nesse sentido, a realidade virtual mediada pelos óculos tem se mostrado inovadora para o cuidado de enfermagem, recurso que modula a atividade cerebral, modifica a forma como a criança interpreta a dor aguda, substitui o foco de atenção (distração) na realização dos procedimentos dolorosos ${ }^{3}$, captura os movimentos da cabeça para determinar o ponto de vista da criança do ambiente virtual e permite a interação humano-computador de navegação pelo ambiente virtual, modificando regiões cognitivas e emocionais do Sistema Nervoso Central, reduzindo a percepção da dor ${ }^{4}$. Buscou-se então compreender a experiência da criança hospitalizada com a realidade virtual em procedimentos dolorosos. Método: Trata-se de um resumo de dissertação, de um estudo exploratório descritivo, com abordagem qualitativa, realizado na clínica pediátrica de um Hospital Escola, da rede pública Federal de Alagoas, com parecer do Comitê de Ética no 2.857.902. A obtenção das informações ocorreu no período de outubro a dezembro de 2018, seguindo as etapas: identificação da criança com necessidade de procedimento doloroso, análise de conteúdo segundo Bardin, levantamento das informações, aplicação da escala de dor comportamental, observação da criança durante o cuidado de enfermagem e entrevista com acompanhante ao fim do procedimento doloroso. Utilizou-se óculos de realidade virtual tridimensional, com lente ajustável, adaptado ao smartphone, que captura os movimentos da cabeça, permite interação da criança com imagens do aplicativo virtual de safari, montanha russa ou oceano de acesso gratuito. Resultados e discussão: A experiência com a realidade virtual ocorreu com oito crianças, entre 10 a 12 anos de idade, submetidas a procedimentos dolorosos e oito acompanhantes na faixa etária de 27 a 40 anos, com tempo de internação entre 1 e 36 dias, nos procedimentos dolorosos: punção venosa periférica, enema, retirada de acesso venoso central, coleta de sangue, curativo de dreno, de ferida operatória e de acesso central. Mediante avaliação da dor pela escala de dor comportamental para crianças, verificou-se que antes do procedimento sete crianças

1 Mestre. Universidade Federal de Alagoas. Email: marcelinhaa17@hotmail.com

2 Doutora. Universidade Federal de Alagoas. Email: ingridmll@esenfar.ufal.br

3 Doutora. Universidade Federal de Alagoas. Email: ana.vieira@esenfar.ufal.br

4 Doutora. Universidade Federal de Alagoas. Email: cicera.albuquerque@esenfar.ufal.br

Correspondência: Rua Afra de Albuquerque Lima, 402. Bairro: São Luiz. Arapiraca- AL.

RE. SAÚD. DIGI. TEC. EDU., Fortaleza, CE, v.4, n.2, p.01-06, ago./dez. 2019.

ISSN: 2525-9563 
apresentaram dor ligeira e uma, dor moderada. Durante o procedimento, três não apresentaram dor, quatro dor ligeira e uma dor intensa. Após, seis não apresentaram dor, uma dor ligeira e uma dor moderada ${ }^{a}$. $\mathrm{Na}$ entrevista com os acompanhantes, verificou-se que o cuidado de enfermagem a criança hospitalizada ocorre de maneira positiva, em atendimento as necessidades da criança. Conclusão: $O$ estudo mostrou que a realidade virtual contribui para uma assistência de enfermagem diferenciada, resulta melhor enfrentamento da dor. A realidade virtual, resultou num efeito positivo biológico, não farmacológico na redução da dor favorecendo a realização dos procedimentos pela equipe, pois a criança apresentava-se mais calma. Ao buscar conhecer como a realidade virtual vem sendo incorporada nos cuidados em saúde, verificou-se que há necessidade de aprofundamento teórico e novos estudos voltados à perspectiva do cuidado à criança no ambiente hospitalar.

Palavras-chave: Terapia de Exposição à Realidade Virtual. Dor. Criança Hospitalizada.

\section{Abstract}

Introduction: During child hospitalization, painful procedures are reflected in the well-being, communication and continuity of health care1. One of the concerns of the nursing staff is pain relief and child comfort, especially in invasive procedures ${ }^{2}$. In this sense, glasses-mediated virtual reality has proven to be innovative for nursing care, a feature that modulates brain activity, changes the way children interpret acute pain, replaces the focus of attention (distraction) in performing painful procedures ${ }^{3}$, captures head movements to determine the child's point of view of the virtual environment and allows human-computer interaction of navigating the virtual environment, modifying cognitive and emotional regions of the central nervous system, reducing pain perception4. We then sought to understand the hospitalized child's experience with virtual reality in painful procedures. Method: This is a dissertation summary, a descriptive exploratory study with a qualitative approach, carried out at the pediatric clinic of a teaching hospital of the Federal Public Network of Alagoas, with the opinion of the Ethics Committee No. 2,857,902. The information was obtained from October to December 2018, following the steps: identification of the child in need of a painful procedure, content analysis according to Bardin, information gathering, application of the behavioral pain scale, observation of the child during nursing care and interview with a companion at the end of the painful procedure. We used three-dimensional adjustable virtual reality glasses, with adjustable lens, adapted to the smartphone, which captures the movements of the head, allows interaction of the child with images of the free safari, roller coaster or ocean virtual application. Results and discussion: The experience with virtual reality occurred with eight children, aged 10 to 12 years, undergoing painful procedures and eight companions in the age group of 27 to 40 years, with hospitalization time between 1 and 36 days, in the painful procedures: peripheral venipuncture, enema, central venous access removal, blood collection, drain dressing, surgical wound and central access. By assessing pain by the behavioral pain scale for children, it was found that before the procedure seven children had mild pain and one moderate pain. During the procedure, three had no pain, four mild pain and one severe pain. After, six had no pain, one mild pain and one moderate pain. In the interview with the caregivers, it was found that nursing care for hospitalized children occurs positively, meeting the child's needs. Conclusion: The study showed that virtual reality contributes to a differentiated nursing care, resulting in better coping with pain. Virtual reality resulted in a positive biological, non-pharmacological effect on pain reduction, favoring the procedures performed by the team, as the child was calmer. In seeking to know how virtual reality has been incorporated into health care, it was found that there is a need for theoretical deepening and new studies focused on the perspective of child care in the hospital environment. 
Keywords: Virtual Reality Exposure Therapy. Pain. Hospitalized child.

\section{Trabalho original}

Farias, MB de. A experiência da criança hospitalizada com a realidade virtual no cuidado de enfermagem em procedimentos dolorosos. 2019. 85 f. Dissertação (Mestrado em Enfermagem) - Escola de Enfermagem e Farmácia, Programa de Pós-Graduação em Enfermagem, Universidade Federal de Alagoas, Maceió, 2019. Disponível em: http://www.repositorio.ufal.br/handle/riufal/5801

\section{Referências}

1- Freitas, B.H.B.M.; Voltani, S.S.A.A. Therapeutic play in the pediatric urgent and emergency department: an integrative literature review. Cogitare Enferm, v.21, n.1, p. 1-8, jan-mar. 2016. Disponível em: < file:///C:/Users/win10/Downloads/4 0728-169625-3-PB.pdf>. Acesso em: 10 abr. 2019.

2- Caleffi, C.C.F. et al. Contribuição do brinquedo terapêutico estruturado em um modelo de cuidado de enfermagem para crianças hospitalizadas. Rev Gaúcha Enferm, v.37, n.2, p. 0108, 2016. Disponível em: < http://www.scielo.br/pdf/rgenf/v37n 2/0102-6933-rgenf-1983144720160258131.pdf >. Acesso em: 02 set. 2018.

3- Scapin, S.Q. Realidade virtual como terapia complementar na recuperação de crianças e adolescentes que sofreram queimaduras: estudo clínico controlado não randomizado. 2018. Disponível em: $<$ https://repositorio.ufsc.br/bitstrea $\mathrm{m} /$ handle/123456789/189164/PN FR1034-D.pdf?sequence $=-$ 1\&isAllowed $=\mathrm{y}>$. Acesso em: 10 set. 2018.

4- Laviola, J.J.; Kruijff, E.; Mcmahan, R.P.; Bowman, D.; Poupyrev, I.P. 3D User Interfaces: Theory and Practice. Pearson Education, 2nd edition, 2017.

RE. SAÚD. DIGI. TEC. EDU., Fortaleza, CE, v.4, n.2, p.01-06, ago./dez. 2019. ISSN: 2525-9563 


\section{Anexos}

Escala Comportamental da dor aguda e observações da pesquisadora. Out- dez/ 2018. Fonte: Farias, MB. 2019.

\begin{tabular}{|c|c|c|c|c|}
\hline \multirow[b]{2}{*}{ Criança } & \multicolumn{3}{|c|}{ Escala } & \multirow[b]{2}{*}{$\begin{array}{l}\text { Observações da pesquisadora } \\
\text { durante o procedimento } \\
\text { doloroso mediado pela RV }\end{array}$} \\
\hline & $\begin{array}{l}\text { Momento que } \\
\text { antecede o } \\
\text { procedimento }\end{array}$ & $\begin{array}{l}\text { Momento ao } \\
\text { decorrer do } \\
\text { procedimento } \\
\text { com a RV }\end{array}$ & $\begin{array}{c}\text { Momento } \\
\text { posterior ao } \\
\text { procedimento }\end{array}$ & \\
\hline Batman & 2 & (1) & 0 & $\begin{array}{l}\text { Antes da retirada do curativo de } \\
\text { dreno, reclamou com medo. } \\
\text { Durante se incomodou no começo, } \\
\text { se movimentando ao ser retirado o } \\
\text { curativo, contudo após esse } \\
\text { momento, focou no vídeo e ficou } \\
\text { relatando a história que se passava } \\
\text { em detalhes. }\end{array}$ \\
\hline $\begin{array}{l}\text { Mulher } \\
\text { Maravilha }\end{array}$ & 1 & 0 & 0 & $\begin{array}{l}\text { Antes da punção venosa, } \\
\text { apresentou-se tensa, durante o } \\
\text { procedimento, não esboçou } \\
\text { nenhuma reação, ao término } \\
\text { sorriu. }\end{array}$ \\
\hline $\begin{array}{l}\text { Capitão } \\
\text { América }\end{array}$ & 1 & 0 & 0 & $\begin{array}{l}\text { Apreensivo antes da coleta de } \\
\text { sangue, porém durante o } \\
\text { procedimento ficou concentrada } \\
\text { em alguns momentos e em outros } \\
\text { relatando a história do vídeo, ao } \\
\text { finalizar tocou no curativo para } \\
\text { confirmar se havia sido realizado o } \\
\text { procedimento. }\end{array}$ \\
\hline Huck & 2 & 1 & 0 & $\begin{array}{l}\text { Antes da retirada do AVC, } \\
\text { apresentou-se apreensivo e } \\
\text { reclamando que ia doer, logo no } \\
\text { início do procedimento, reclamou } \\
\text { uma vez de dor e depois relaxou, } \\
\text { movimentando os dedos como se } \\
\text { acompanhasse o vídeo, ao } \\
\text { término, ficou sem acreditar que já } \\
\text { havia sido realizado. }\end{array}$ \\
\hline $\begin{array}{l}\text { Mulher } \\
\text { Gato }\end{array}$ & 2 & 1 & 0 & $\begin{array}{l}\text { Antes da punção venosa periférica } \\
\text { estava segurando a mão da mãe e } \\
\text { apreensiva, durante mexeu-se } \\
\text { algumas vezes e ao término contou } \\
\text { à mãe o que apareceu no vídeo. }\end{array}$ \\
\hline LadyBug & 4 & 3 & 1 & $\begin{array}{l}\text { Antes da realização do enema } \\
\text { apresentou sudorese acentuada e } \\
\text { choramingos, mas foi se } \\
\text { acalmando à medida que se fixava } \\
\text { no vídeo, porém segurada na mão } \\
\text { da mãe durante todos os } \\
\text { momentos, ao término apresentou- } \\
\text { se calma e aliviada. }\end{array}$ \\
\hline $\begin{array}{l}\text { Homem } \\
\text { Aranha }\end{array}$ & 1 & 0 & 0 & $\begin{array}{l}\text { Antes do curativo de ferida pós } \\
\text { operatória, perguntou se ia doer. } \\
\text { Narrou o vídeo, durante todo o }\end{array}$ \\
\hline
\end{tabular}




\begin{tabular}{|c|l|l|l|l|}
\hline & & & $\begin{array}{l}\text { procedimento. Ao término, contou } \\
\text { para a mãe o que havia visto. }\end{array}$ \\
\hline $\begin{array}{c}\text { Super } \\
\text { Homem }\end{array}$ & 2 & 7 & $\begin{array}{l}\text { Antes da punção venosa periférica, } \\
\text { apresentou-se apreensivo e sem } \\
\text { querer deixar realizar. Na primeira } \\
\text { tentativa de punção venosa, ficou } \\
\text { concentrado no vídeo e contando o } \\
\text { que ocorria na história, nas outras } \\
\text { tentativas de punção venosa } \\
\text { apresentou-se nervoso } \\
\text { gemendo. }\end{array}$ \\
\hline
\end{tabular}

RE. SAÚD. DIGI. TEC. EDU., Fortaleza, CE, v.4, n.2, p.01-06, ago./dez. 2019.

ISSN: 2525-9063 


\section{Como citar este artigo}

Farias MB; Lúcio IML; Vieira ACS, Albuquerque MCS. A experiência da realidade virtual com crianças em procedimentos dolorosos. Revista de Saúde Digital e Tecnologias Educacionais. [online], volume 4, n. 2. Editor responsável: Luiz Roberto de Oliveira. Fortaleza, mês e ano, p.01-06. Disponível em: http://periodicos.ufc.br/resdite/index. Acesso em "dia/mês/ano".

Data de recebimento do artigo: 25/09/2019

Data de aprovação do artigo: 23/11/2019

RE. SAÚD. DIGI. TEC. EDU., Fortaleza, CE, v.4, n.2, p.01-06, ago./dez. 2019.

ISSN: 2525-9063 